\title{
José Angel Gutiérrez: Professor, Politician, and Political Activist
}

\section{Natalie Thomas}

Dr. José Angel Gutiérrez recently retired from the Political Science Department at the University of Texas at Arlington, where he has been a popular and impactful professor. But throughout his life he has been so much more than a University professor. I met with him in the Spring of 2015, his last semester at UTA, to learn more about his life, activism, and hopes for the future. Born in 1944, in Crystal City, Texas, Dr. Gutiérrez grew up surrounded by discrimination and racism against Mexican Americans. His small South Texas town had prominently displayed "Whites Only" signs on restaurant and store windows. It was these early life experiences that motivated him to make the issues of the Mexican American communities heard and change lives for the better. Gutiérrez was the first Mexican American student body president at his high school and looked up to his principal as an example of a great leader. But when his principal demanded segregation at the prom, Gutiérrez was filled with rabia and could no longer see a hero in the man. He strove to end discrimination and racist acts like the one committed by his former principal.

Dr. Gutiérrez graduated from Texas A\&M Kingsville in 1966 before attending St. Mary's University in San Antonio to complete his M.A. in political science. It was here at St. Mary's that he founded the Mexican American Youth Organization with Mario Compeán, Juan Patlán, Nacho Pérez, and Willie Velásquez. MAYO is credited as one of the first student activist organizations of the developing Chicano movement. Eight years after he finished high school, Gutiérrez returned to Crystal City and became the President of the School Board; he formally demoted his old principal.

After returning to Crystal City, the "La Raza Unida" political party came to be. Gutiérrez and other Mexican American political activists in the area witnessed intense racial discrimination in the local schools and after a massive walk out by students in December 1969, the school board in Crystal City conceded to the demands of the Latino students to end educational inequalities. This walk out and the attention it garnered in the area displayed the power of the Latino community and its numbers. In the spring of 1970, the activists in Crystal City decided to put up 16 Mexican American candidates in the local elections of Crystal City, Carrizo Springs, Cotulla, and Robstown. 15 of the 16 candidates won their elections and "La Raza Unida" gained national attention. Chapters in 17 states and the District of Columbia popped up and Dr. Gutiérrez was elected the national party chairman in 1972. Alas, by 1979, the Texas Legislature had outlawed the 
political party, but not before La Raza Unida had had an impact on the Democratic and Republican parties.

Dr. Gutiérrez has accomplished many things in his life outside La Raza Unida. He has written 14 books, his last of which he worked on with his wife. This book, Chicanas in Charge, was one of his favorites to write because he loved collaborating with his wife. He calls Chicanas in Charge a "labor of love" that was engaging and helped him and his wife come together academically. Dr. Gutiérrez has contributed to numerous scholarly projects, interviewed over 200 Mexican-Americans and been a professor in both Oregon and Texas.

Teaching is what he was most known for on the University of Texas at Arlington campus, where he had been a mentor for the McNair Scholars program and the Honors College. He also founded the Center for Mexican American Studies here. He loved teaching at UTA, but said there were definite differences between Texas and Oregon. The first time he ever saw poor white people was when he taught in Oregon, where the only drawback was the weather. In Texas, however, attitudes tend to be fairly negative and more conservative. Dr. Gutiérrez received criticism for teaching his class from a Chicano perspective and using his real life experience and practice to bring a more enriching education to students. He required service learning and voter registration and encouraged students to be active members of their communities. Political Science majors usually gave him glowing reviews, but outside the department he was controversial because of his defense of marginalized and minority groups, including women and African Americans.

Outside of the university environment, Dr. Gutiérrez said that he had many hopes for the future of American politics. He wants to see a Hispanic president of the United States. He hopes that Julian and Joaquin Castro will achieve more influence in the Democratic Party. In Texas, he would like to see a Chicano/ Chicana governor. He wants to see a drop in unemployment in the Valley and an end to gerrymandering. In short, Dr. Gutiérrez dreams of a government that is more representative of the people it serves.

Dr. Gutiérrez also hopes for a better future for Mexican Americans, as the current situation is not good in his eyes. He predicts that Chicano culture will die within the next couple decades. Thirty states in the US have adopted "English-only" laws, bills like SB 1819 in the Texas legislature are attempting to repeal the DREAM Act, and five of the nine state history books don't even mention Mexican American history and the relations between Mexico and Texas. Dr. Gutiérrez said there has been a loss in identity for Mexican Americans; when speaking English, he said, most will claim they are "Hispanic" or "Latino" rather than Mexican American and most second and third generation Mexican Americans don't speak Spanish - "a huge disrespect for their own culture." In response to SB 1819, Dr. Gutiérrez said there would be a terrible economic loss for the state if the DREAM Act was repealed and that more than 2.3 million students would be affected nationwide if other states followed. "The sponsors of the bill are essentially saying that Mexicans are the enemy." In order to improve these situations, "the new generations must bring something, anything, to the table." Older Chicano generations fought for civil rights, built an agenda and social capital, "but the new generations have brought nothing" and so there will be little to no progress in the future.

But Dr. Gutiérrez isn't done creating change. He plans on writing at least three more books, conducting more interviews, and working in politics on behalf of Mexican Americans. Dr. Gutiérrez took his leave by saying "we go in to try to change the institution, but we must leave before the institution changes us. Bueno, bye!" 